\title{
SECTORIAL ANALYSIS OF NPAS IN NAINITAL BANK LTD, A LOCAL AREA SCHEDULED COMMERCIAL BANK IN UTTARAKHAND
}

\author{
MUKESH SHARMA $^{1} \&$ VPS. ARORA ${ }^{2}$ \\ ${ }^{I}$ Scholar, School of Management Studies, Shri Venkateshwara University, Gajraula, Uttar Pradesh, India \\ ${ }^{2}$ Professor Emeritus, School of Business Studies, Sharda University, Greater Noida, Uttar Pradesh, India
}

\begin{abstract}
In the present financial world, non-performing asset (NPA) is not a buzz word only rather it has become the a serious concern to the entire banking industry which reflects the performance of the bank, this chronic problem have raised the a prime question of the survival before every Indian commercial bank irrespective to their ownership, management \& control either as a public sector or a private sector bank. These NPAs grab upon a large share of profit and net worth, which turn out to be an ultimate loss to the banks besides the stake holder value. As soon as the volume of NPAs in any bank is increase with a rapid pace the bank runs out of liquidity. NPA, the two edged weapon, the first edge it stops earnings on the account in form of interest \& other charges etc. and at the other as per RBI's IRAC guidelines which imposes upon the bank to make a huge sum of provisions from already $P$ \& L account, ultimately likewise this weapon adversely affects not only theoverall profits but also restricts the business cycle of the bank of credit \& advances portfolio which will ultimately cripple the banking industry. The crash of the banking sector will severely hamper the functioning of other sectors of the economy of the nation through unfavourable effects on various growth parameters like GDP, Unemployment Rate and PCI etc. Keeping in view the impact of NPAs, a banker should be quite cautious while lending loan \& credit to any sector, since the funds being landed is the public money mobilised by the bank in form deposits, corporate bonds, debentures, government shares etc. Due to the imprudent credit decisions of the banking system is one of the paramount reasons of mounting NPAs are year by year. On the basis of all above cause the present study is conducted to examine the credit expanded in different sectors and the reasons for becoming them NPA in Nainital Bank Limited, operating in Uttarakhand and to give suitable suggestions to overcome the mentioned problem.
\end{abstract}

KEYWORDS: NPAs, Total Advances, Sectors, Nainital Bank Limited, GDP, PCI \& Unemployment Rate

Received: Aug 18, 2020; Accepted: Sep 08, 2020; Published: Oct 19, 2020; Paper Id.: IJBMROCT20203

\section{INTRODUCTION}

For the development of any nation, banking system plays a significant role since it boosts the economy by mobilizing funds in form of public money and simultaneously investingit among different sectors of economy the country. As per 'World Economic Forum' India is considered to be the 5th largest economy of the world growing on fastest pace. India is also having the huge market for the foreign investors to earn profit from their investments, as the India is the second largest populated country in the world. So, whatever is manufactured in India is predominantly consumed in India itself. However, sectorial development requires fund to be raised by the equity shareholders for the expansion of the business. These funds are raised in the form of debt from the banks. So, banks by expanding such debt in form of loans \&advances to the different sectors of economy frame the backbone of the country. As per Section 5 (b) of Banking Regulation Act 1949 "Banking" means "Accepting for the purpose of lending or Investment, of deposits of money from the public, repayable on demand or otherwise and withdrawal by 
cheque, draft order or otherwise."

The third phase of banking reforms called the phase of economic liberalization after Class Banking (the first banking phase up to 1969, before nationalization of 14 major banks) and Mass Banking (the second banking phase from 1969 to 1991). Both the phases before 1991, in first phase of Class Banking the focus was merely on profit through the selected class of customers, industries, trade \& commerce etc., which with a drastic change shifted to Mass banking in which banks were merely focusing on building small assets to masses in the field of Agriculture\& Allied Activities, S.S.I.and other priority sector. This was the phase when a good number of directed government lending programmes to cater the need of rural India were launched. In this phase the main focus was on the branch expansion of the public sector banks with the prime idea of the development of Rural India.

The Indian banking system, a well-organized set upmobilises funding resources to lend by offering numerous interest based variable schemes to the public, tempts public to invest their surpluses and earn interest-based profit on the basis of opted maturity period. Henceforth, the banks lend these public funds to various sectors of economy such as agriculture, industry, service sectors besides through a long range of retail products such as housing, vehicle, personal, trade \& commerce loans etc. apart Export-import landings through various products \&services. The basic working model of banking system is to pay a bit lower return on mobilised deposits to expand credit and on the contrary charging a bit higher in form of interest on that fund landed. But in present scenario, the banking system incurs losses due to its mounting Non-Performing Assets portfolio which hampers the recycling of bank funds in a profitable manner. So every sector in the country [1-2]. So, the banks became very cautious in lending loans to any business [3]. This composite study is conducted to analyse the main sectors which are defaulting and their cause of illness which are ending up in NPAs. This study is carried on the 10 years data during March, 2009 to March, 2018 of Nainital Bank Limited; a local area scheduled commercial bank, operating in five states of northern India such as Uttarakhand, UP, Haryana, Rajasthan \& Delhi NCR.

\section{REVIEW OF LITERATURE}

The rapid increase in the level of NPA has become a serious concern to not only to the bankers but also to the government, in fact both want to curb it by any means. Since the issue become grave hence drawn attention of several researchers those diagnosed and discussed this critical issue thread bare to understand the causes and proposed some remedial measures to control it.

A review of such research work has been briefly discussed below:

In [4] a study was carried on the NPAs occurred in Indian public sector banks, a case of State Bank of Mysore in special reference to agricultural sector and proposed few remedies which can be followed to protect the conversion of further advances into NPAs. The proposed remedy, which suggests the banker to avoid sanctioning loans to the seeker whose credentials are not trustworthy. For such cases, the project for which loan is being asked, should be examined carefully which concerns the economic viability and the return on investment of the project. If both of them are well defined and the expected returns are much larger than the credited amount than the loan could be sanctioned with a continuous monitoring on the progress of the project and this is called as post sanction inspection.

Kumar [5] performed their studies on the occurrence of NPAs in private sector and foreign banks and concluded that the accumulation of NPAs in late 90s resulted in the big challenge for the survival of the bank. They also found that the banker shall have to choose the loan allocation portfolio very carefully. Otherwise, the negligence in choosing the correct 
portfolio will results in NPAs and consequently it will affect the profitability, productivity, liquidity and ultimately the image of the bank [6].

Vadivalagan et al. [7] carried out the analysis and concluded that the growth of Indian banks is more in lending loans to the priority sectors as compare to the non-priority sectors. The banks already suffered a lot due to negligence in loan disbursements in past few decades. Henceforth, a proper monitoring system is required during loan disbursement and the pending NPAs should also be tried to recover so that the banks could not lose their capital anymore and maintains its capital adequacy and profitability.

In [8] Singh proposed in his research about the rapid increments in NPAs due to defaulted credit risk management of the bank. This facility should have performed an adequate appraisal of the proposed model before sanctioning the loan. This may help the bank to estimate the scope of the project and proper decision could be taken for the loan disbursement. The post disbursement supervision of the project is also suggested by them. The bank should also have the power to release funds to the loanee while purchasing some expensive equipment for the project which helps the bank in properly monitoring the amount being invested by the loanee.

Gupta [9] in his study had clearly stated about the various measures which are to be taken for preventing further NPAs in any bank. He suggested to have an independent credit rating agency of every bank, which can evaluate the past performance and current financial status of the borrower. Every bank should form a special committee of financial experts which can deeply analyse the financial status and the work profile of each borrower before taking decision of loan disbursement. Subsequently, after loan disposal, a special account should be created for every borrower for reviewing their performance and correspondingly generate a loan concentration report every month.

In [10] Rai have discussed about the occurrence of NPAs in Indian commercial banks and stated that in the past decades the borrower does not have any fear of being default as there was no guidelines about the legal proceeding, which would be initiated by a bank to safeguard their interest. However, after introducing SARFAESI ACT, the banks have got a power to issue a legal notice against the borrower for the repayment of the solicited loans. Recently, Supreme Court has assigned a special power to the bank, according to which a bank can sell the mortgage property of the borrower in negligence of the aforementioned legal notice. This handed a special power to the banks to recover their loans after NPAs.

In [11] Khanna mainly focuses on the management of NPAs in Indian commercial banks as the banks are lending loans in various sectors such as agriculture, industry, retail, services and others etc. Nowadays, the banks are very cautious in lending due to high deranged NPAs in Indian banking. The rapid increments in number of NPAs are directly affecting the cash flow, capital adequacy, profitability and value of the banks.

In [12] Das et al. have thoroughly discussed the guidelines to manage NPAs. Their proposal is to first check the genuineness of the borrower and the purpose of seeking loan along with the wealth analysis of the guarantor and his capacity of repaying loan in case of NPA occurs by the borrower. Moreover, the banks should frame proper rules and guidelines for availing loan by which a borrower is bound to produce a six-monthly balance confirmation certificate to the bank. On following these guidelines, the bank may further put an end on being fresh NPAs. Banks should have a weekly self-appraisal for emphasising on the reduction of gross NPAs instead of Net NPAs. 


\section{RESEARCH OBJECTIVES}

The main objective of the paper is to compare the NPA trends in last past 10 years in different sectors identified for loans \&advances sanctioned and disbursed by The Nainital Bank Limited in Uttarakhand. The second objective includes the comparison of gross\& net NPAs in Nainital Bank Limited against the total loan\&advances sanctioned and disbursed to various sectors of lending in last past 10 years in Uttarakhand. The third objective is the analysis of NPAs versus total advances in every sector and try to establish (if any) relation among them and to identify the sector which suffered the most. The intent was to enlist the causes and the remedies of the occurrence of NPAs in Nainital Bank Limited.

\section{RESEARCH METHODOLOGY}

This research study mainly focuses on the data collected through various web sources like Annual Reports of the bank as well MCI site along with various bulletins, journals and other sources such as SLBC \& DLCC Reports.

The descriptive analysis done on the collected data is required to examine the major factors which are affecting the bank performance in the context of the NPAs. To perform the curve analysis, the NPA being the independent parameter versus the total advances offered by the bank over the period of 10 years (FY 2009 to FY 2018). With the change in NPA in different sectors the analysis is carried on to identify the major sectors suffered with NPA menace and to bring out the factors which can be further rectified to prevent the losses incurred by the bank due to NPAs. The independent analysis is performed for every sector and finally the comparative analysis is done to identify the suffering sector.

\section{RESULTS AND DISCUSSIONS}

In the coming section, the results obtained from the data analysis on total advances lent by Nainital Bank Limited to different sectors operating in state of Uttarakhand are presented in the form of tables and diagrams.

Table 1: NPAs in Various Sectors against the Loans Offered by The Nainital Bank Limited

\begin{tabular}{|c|c|c|c|c|c|c|c|c|c|c|c|c|c|c|c|}
\hline \multirow[b]{2}{*}{ Year } & \multicolumn{3}{|c|}{ Agriculture Sector } & \multicolumn{3}{|c|}{ Industry Sector } & \multicolumn{3}{|c|}{ Services Sector } & \multicolumn{3}{|c|}{ Retail Sector } & \multicolumn{3}{|c|}{ Others Sector } \\
\hline & $\begin{array}{c}\text { Total } \\
\text { Advances }\end{array}$ & $\begin{array}{l}\text { Gross } \\
\text { NPA }\end{array}$ & $\begin{array}{c}\% \\
\text { NPA }\end{array}$ & $\begin{array}{c}\text { Total } \\
\text { Advances }\end{array}$ & $\begin{array}{l}\text { Gross } \\
\text { NPA }\end{array}$ & $\begin{array}{c}\% \\
\text { NPA }\end{array}$ & $\begin{array}{c}\text { Total } \\
\text { Advances }\end{array}$ & & $\mid \begin{array}{c}\% \\
\text { NPA }\end{array}$ & $\begin{array}{c}\text { Total } \\
\text { Advances }\end{array}$ & & $\begin{array}{c}\% \\
\text { NPA }\end{array}$ & $\begin{array}{c}\text { Total } \\
\text { Advances }\end{array}$ & & $\begin{array}{c}\% \\
\text { NPA }\end{array}$ \\
\hline 2009 & 122.02 & 1.25 & 1.02 & 67.25 & & 1.75 & 8.05 & & 2.36 & 109.26 & 1.98 & 1.81 & & 0.67 & 0.61 \\
\hline 2010 & 142.04 & 1.40 & 0.99 & 84.64 & & & 13.18 & & & 125.06 & 2.38 & 1.90 & & 0.86 & 50 \\
\hline 2011 & 196.64 & 0.88 & 0.45 & 48.08 & & 0.31 & 22.28 & 0.10 & 0.45 & 163.83 & 1.49 & 0.91 & 239.14 & 0.62 & 0.26 \\
\hline 2012 & 252.77 & 1.96 & 0.78 & 68.26 & 0.14 & .21 & 29.13 & 0.26 & 0.89 & 196.25 & 1.45 & 0.74 & & 2.01 & 0.82 \\
\hline 2013 & 298.65 & & 4.95 & & & 42 & & & 1.13 & & & 0.70 & & 1.25 & 0.36 \\
\hline 2014 & & & & & & & & & 0.64 & & 1.19 & 0.47 & & 1.27 & 0.34 \\
\hline 2015 & 303.66 & 9.42 & 3.10 & & & 3.64 & & & 3.11 & & 4.34 & 1.51 & & 3.02 & 1.04 \\
\hline 2016 & 313.69 & & 6.36 & 263.75 & & & & & 7.02 & & 13.66 & 4.54 & & 13.36 & 4.38 \\
\hline 2017 & 551.10 & & 5.45 & 501.7 & & & 100.99 & & 6.21 & & 11.35 & 3.90 & & 7.73 & 2.82 \\
\hline 2018 & 506.03 & 34.62 & 6.84 & 260.34 & 3.2 & 1.23 & 110.38 & 6.07 & 5.50 & 305.21 & 13.03 & 4.27 & 547.254 & 7.53 & 1.38 \\
\hline
\end{tabular}

The primary analysis was performed on each individual sector working in the state. Henceforth, their comparative studies are carried on for determining the most vulnerable sector, which resulted in more number of NPAs against the total advances made during last past 10 years. The data existing in table 1 are the data from five different sectors and the bar graphs are plotted in figure 1 (a) to 1 (e) are for the gross NPAs for each sector like agriculture, industry, services, retail 
and others respectively.

The analysis performed from figure 1 (a) on agriculture sector shows that the number of NPAs in first four years were low but an immediate spike was seen in 2013 which jumped from 1.49 (in 2012) to 14.00 crores followed by a rapid increment every year and reaches up to 34.62 crores in 2018. However, a slight decrement can be noticed in the year 2015, which drew attention on the strategies which were followed in that particular year.

The second finding drawn from figure 1 (b) shows performance of the industry sector, which were quiet satisfying during first six years but in the year 2015 a sudden increment in NPAs can be seen, which further gradually reduced in the next three years. Moreover, this particular sector shows a satisfactory result in comparison to the former sector.

The remaining three sectors performed well in their first six years especially services sector, but a rapid increment is seen in every sector after the year 2015. The results are shown in figure 1 (c) to 1 (d).

(a) NPAs in Agriculture Sector

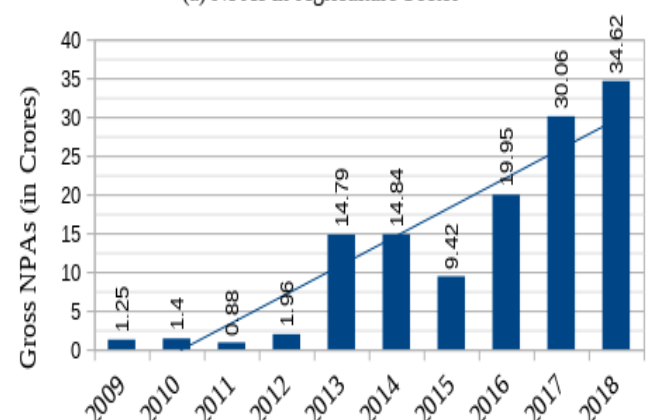

(c) NPAs in Service Sector

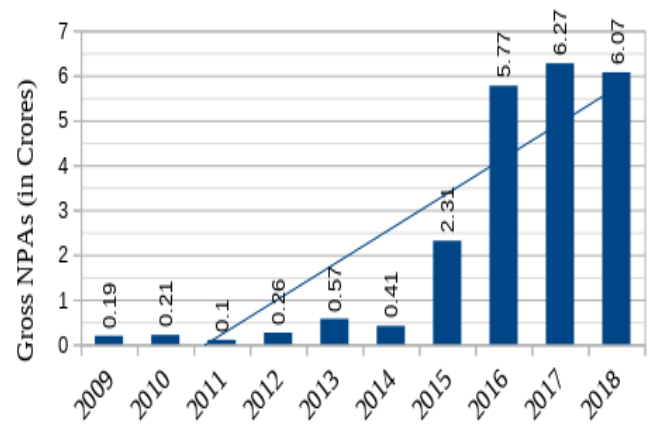

(b) NPAs in Industry Sector

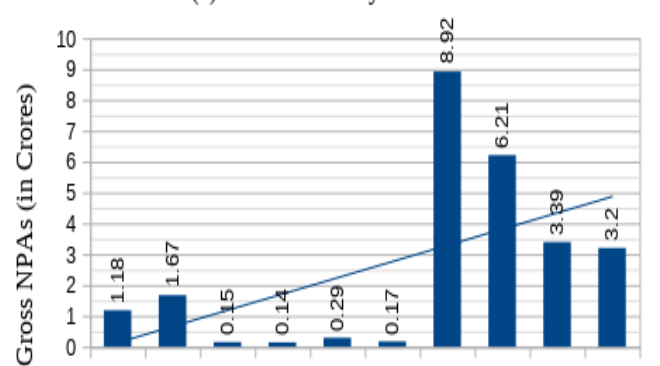

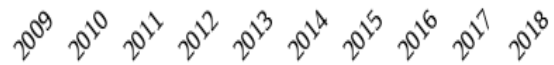

(d) NPAs in Retail Sector

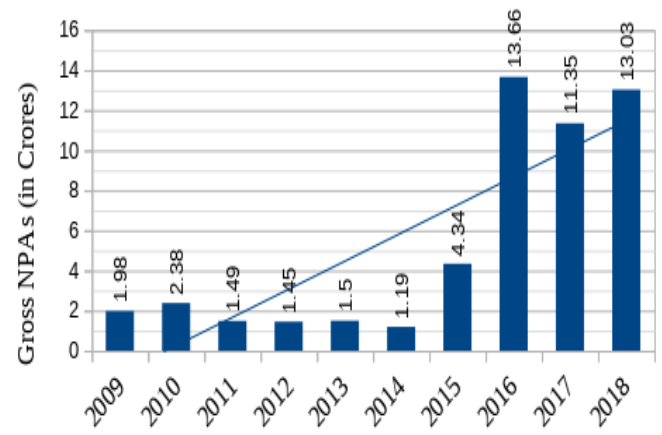

(e) NPAs in Other Sector

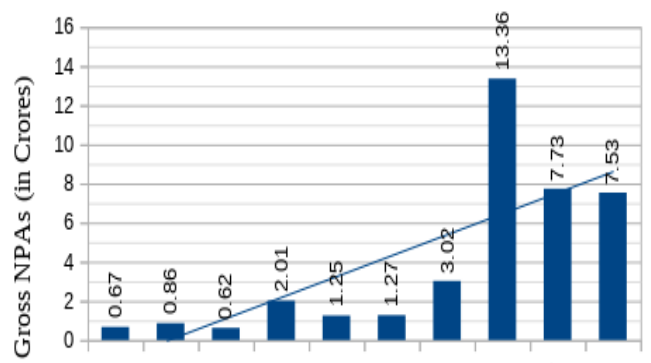

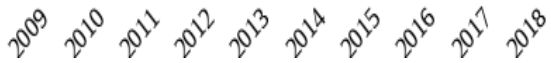

Figure 1: NPAs in Various Sectors against the Loans Offered by The Nainital Bank Ltd. During 10 Years. 
Table 2: Total Advances Outstanding in Various Sectors by The Nainital Bank Limited (in Crores)

\begin{tabular}{|c|c|c|c|c|c|}
\hline Year & Agriculture & Industry & Services & Retail & Others \\
\hline $\mathbf{2 0 0 9}$ & 122.02 & 67.25 & 8.05 & 109.26 & 110.18 \\
\hline $\mathbf{2 0 1 0}$ & 142.04 & 84.64 & 13.18 & 125.06 & 145.53 \\
\hline $\mathbf{2 0 1 1}$ & 196.64 & 48.08 & 22.28 & 163.83 & 239.14 \\
\hline $\mathbf{2 0 1 2}$ & 252.77 & 68.26 & 29.13 & 196.25 & 246.55 \\
\hline $\mathbf{2 0 1 3}$ & 298.65 & 69.83 & 50.53 & 213.91 & 346.5 \\
\hline $\mathbf{2 0 1 4}$ & 386.07 & 105.51 & 64.02 & 252.05 & 378.77 \\
\hline $\mathbf{2 0 1 5}$ & 303.66 & 244.94 & 74.37 & 287.72 & 291.56 \\
\hline $\mathbf{2 0 1 6}$ & 313.69 & 263.75 & 82.18 & 300.77 & 304.68 \\
\hline $\mathbf{2 0 1 7}$ & 551.10 & 501.7 & 100.99 & 290.66 & 273.65 \\
\hline $\mathbf{2 0 1 8}$ & 506.03 & 260.34 & 110.38 & 305.21 & 547.25 \\
\hline
\end{tabular}

The second analysis was conducted on the total advances offered to every sector and the composite results can be drawn from figure 2 which is plotted on the basis of data shown in table 2, looking over the curve which clearly indicates that the maximum advances made to agriculture sector and a significant amount to retail and services sector which forms a linear relationship. The industry sector has drawn the minimum amount among all the sectors. The sector for the others entity is drawing a similar amount as the agriculture sector.

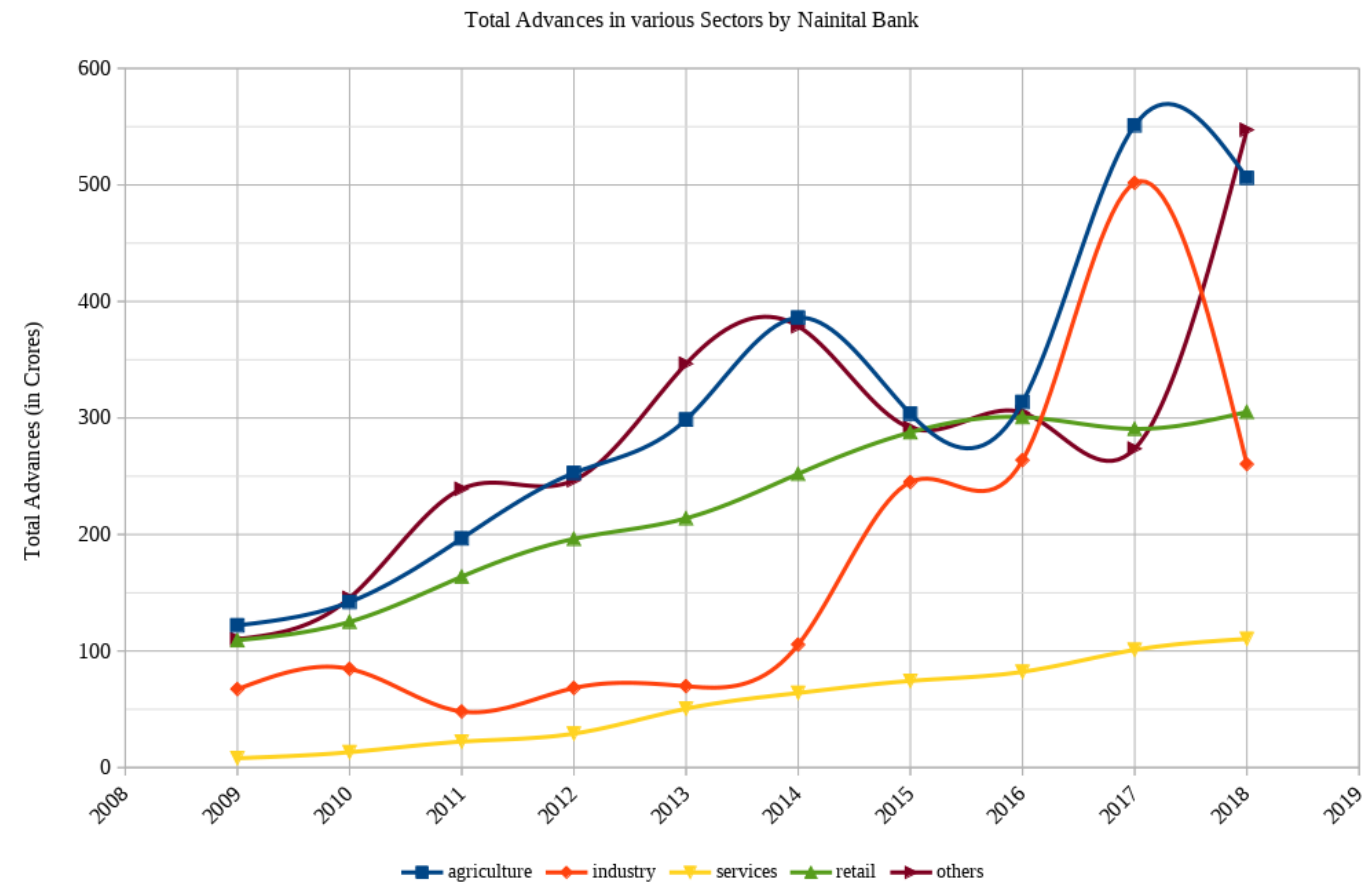

Figure 2: Comparison Curve of Total Advances in Different Sectors by The Nainital Bank Limited.

The third analysis obtained from figure 3 shows that during first four years the gross NPA curve was following a steady state pattern for all sectors and seems that all businesses were running well but sooner after 2012 the results clearly depicts a tremendous outburst in the number of gross NPAs in agriculture sector in the year 2013 and 2014 . However, the remaining sectors were still maintaining the steady response or had a little hike in the end three years. 
Table 3: Gross NPAs in Various Sectors by The Nainital Bank Limited (in Crores)

\begin{tabular}{|c|c|c|c|c|c|}
\hline Year & Agriculture & Industry & Services & Retail & Others \\
\hline $\mathbf{2 0 0 9}$ & 1.25 & 1.18 & 0.19 & 1.98 & 0.67 \\
\hline $\mathbf{2 0 1 0}$ & 1.4 & 1.67 & 0.21 & 2.38 & 0.86 \\
\hline $\mathbf{2 0 1 1}$ & 0.88 & 0.15 & 0.1 & 1.49 & 0.62 \\
\hline $\mathbf{2 0 1 2}$ & 1.96 & 0.14 & 0.26 & 1.45 & 2.01 \\
\hline $\mathbf{2 0 1 3}$ & 14.79 & 0.29 & 0.57 & 1.50 & 1.25 \\
\hline $\mathbf{2 0 1 4}$ & 14.84 & 0.17 & 0.41 & 1.19 & 1.27 \\
\hline $\mathbf{2 0 1 5}$ & 9.42 & 8.92 & 2.31 & 4.34 & 3.02 \\
\hline $\mathbf{2 0 1 6}$ & 19.95 & 6.21 & 5.77 & 13.66 & 13.36 \\
\hline $\mathbf{2 0 1 7}$ & 30.06 & 3.39 & 6.27 & 11.35 & 7.73 \\
\hline $\mathbf{2 0 1 8}$ & 34.62 & 3.2 & 6.07 & 13.03 & 7.53 \\
\hline
\end{tabular}

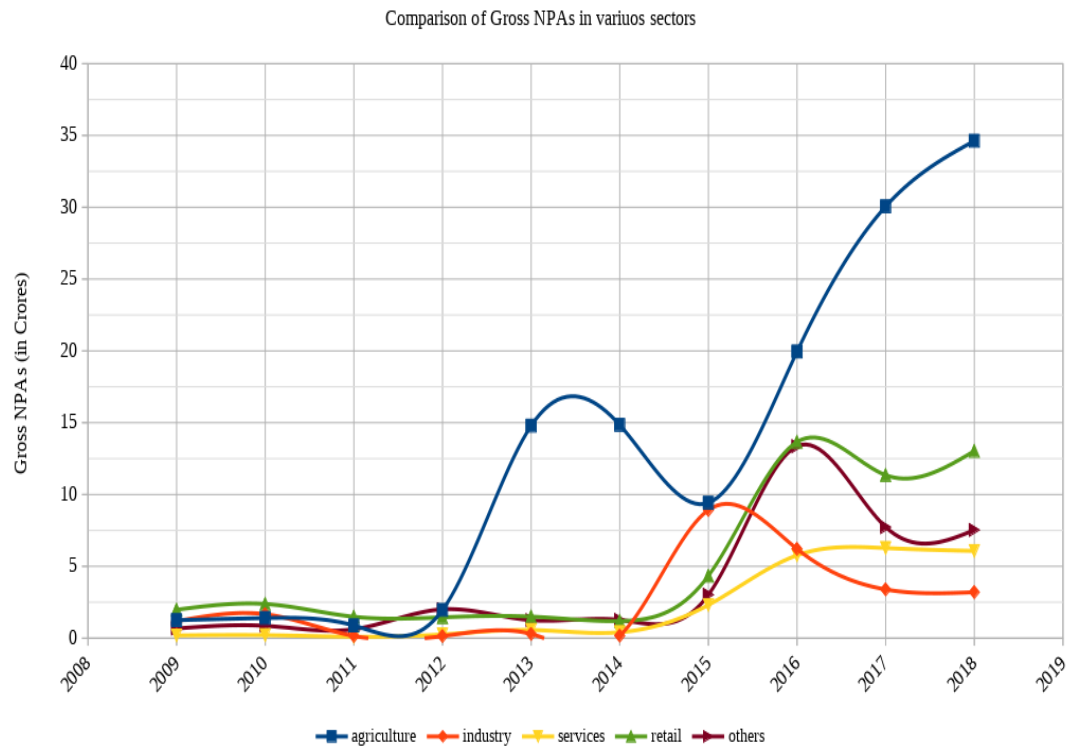

Figure 3:Comparison curve of Gross NPAs in Different sectors by Nainital Bank.

The final conclusion drawn from percentage NPAs curve shown in figure 4, which is the ratio of Gross NPAs to the total advances plotted for each sector. The result clearly indicates that the first four years does not shows enough rise in NPAs in all sectors but a sudden rise in NPAs in agriculture sector was seen. This rise in NPAs creates a barrier to the banks to distribute more advances. Sooner after 2015 every sector shows a rapid increase in NPAs and it becomes a major cause of concern.

Table 4: \% NPAs in Various Sectors by The Nainital Bank Limited

\begin{tabular}{|c|c|c|c|c|c|}
\hline Year & Agriculture & Industry & Services & Retail & Others \\
\hline $\mathbf{2 0 0 9}$ & 1.02 & 1.75 & 2.36 & 1.81 & 0.61 \\
\hline $\mathbf{2 0 1 0}$ & 0.99 & 1.97 & 1.59 & 1.90 & 0.59 \\
\hline $\mathbf{2 0 1 1}$ & 0.45 & 0.31 & 0.45 & 0.91 & 0.26 \\
\hline
\end{tabular}




\begin{tabular}{|l|l|l|l|l|l|}
\hline $\mathbf{2 0 1 2}$ & 0.78 & 0.21 & 0.89 & 0.74 & 0.82 \\
\hline $\mathbf{2 0 1 3}$ & 4.95 & 0.42 & 1.13 & 0.70 & 0.36 \\
\hline $\mathbf{2 0 1 4}$ & 3.84 & 0.16 & 0.64 & 0.47 & 0.34 \\
\hline $\mathbf{2 0 1 5}$ & 3.10 & 3.64 & 3.11 & 1.51 & 1.04 \\
\hline $\mathbf{2 0 1 6}$ & 6.36 & 2.35 & 7.02 & 4.54 & 4.38 \\
\hline $\mathbf{2 0 1 7}$ & 5.45 & 0.68 & 6.21 & 3.90 & 2.82 \\
\hline $\mathbf{2 0 1 8}$ & 6.84 & 1.23 & 5.50 & 4.27 & 1.38 \\
\hline
\end{tabular}

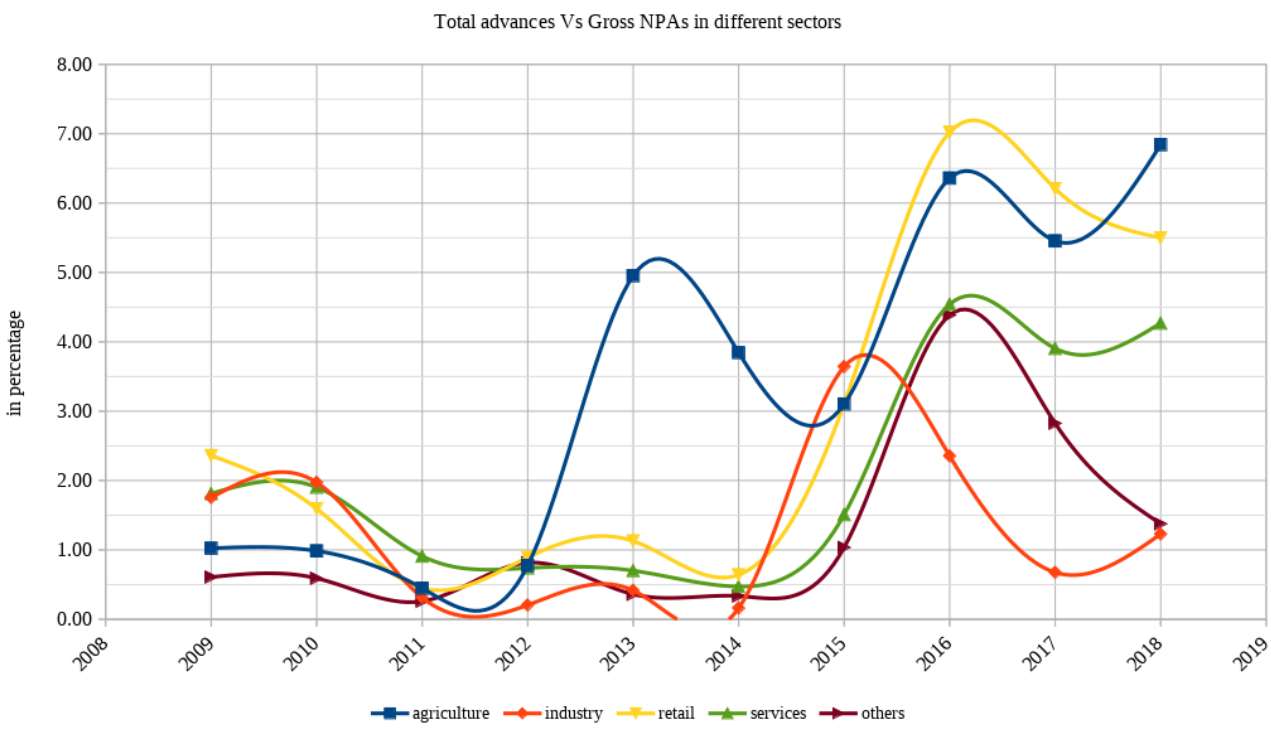

Figure 4: Comparison Curve of \% NPAs in Different Sectors by The Nainital Bank.

\section{CONCLUSIONS}

The overall analysis done one the basis of the objectives of the study carried out for the past 10 years (the study period) w.e.f. $1^{\text {st }}$ April 2008 to $31^{\text {st }}$ march 2019, data of total advances given versus NPAs occurred in different sectors of lending by The Nainital Banks Limited operating in Uttarakhand. Among the various causes said above, the following are the other few critical reasons contributed significantly in the enhancement of NPA level in The Nainital Bank Limited:

- All sectors landed by Nainital Bank very badly affected by the recurrent flood followed by frequent cloud-bursts \&heavy rains in the year 2013, many lives were lost along with severe property loss in the given natural calamity which affected 12 out of 13 districts of Uttarakhand. The borrowers landed for agriculture, Industries, Services, Retail \& other sectors suffered their projects \& their production/revenue cycle followed by non-repayment of bank dues caused incremental growth in NPAs not only in Nainital Bank but in all other banks/FIs. However the SLBC Uttarakhand declared the debt relief scheme in selected sectors for first two years in entire Uttarakhand where the maximum number of branches of The Nainital Bank Limited are situated, in reality the trend of nonrepayment continued for number of years forthcoming up till the study period end i.e. 2018in different sectors identified for loans \& advances sanctioned and disbursed by The Nainital Bank Limited in Uttarakhand.

- Draught in Uttarakhand: In agriculture year 2014-15 \& 2015-16, 9 out of 13 districts affected by severe draught in Uttarakhand was also one of the reasons of poor recovery in agriculture sector mainly followed by increasing 
NPAs in The Nainital Bank Limited. However the SLBC Uttarakhand declared the Debt Relief Scheme for agriculture borrowers for first year only in 8 district of Uttarakhand where majority number of branches of The Nainital Bank Limited situated, in reality the trend of non-repayment continued for number of years then after up till the study periodi.e. 2018in agriculture sectors loans \& advances sanctioned and disbursed by the The Nainital Bank Limited in Uttarakhand.

- After a split from Uttar Pradesh, Uttarakhand state came in existence on $14^{\text {th }}$ February 2002, despite a new state, the government started launching relief measures to the different type of borrowers of all types of banks \& FIs on cause of various calamities taken place in the state e.g. accordingly Uttarakhand government launched an OTS Scheme for agriculture borrowers of Cooperative Banks in the state. Then after the demand from various political parties for such declaration of debt waiver/relief schemes prior state/central elections (for Legislative Assembly in 2012 \& 2017 and for Parliament Assembly in 2009 \& 2014) in order to allure the vote banks has a long term implication on the loan repayment intentions of the borrowers of Uttarakhand.

- Agriculture Debt Waiver Scheme in UP in 2016-17, being the neighbour state, adversely affected the recovery from the borrowers of the adjourning districts on the border of Uttarakhand caused a significant increase in NPAs of different Banks/FIs, including The Nainital Bank Limited, motive/intention of even of the regular borrowers affected likewise even for the future years too.

\section{REFERENCES}

1. Gupta, P. K. (2018). A comparative Analysis on NPAs in Public Sector Banks in India. Research journal of social science, 9(12).

2. Gandhi, K. (2015). Non-performing assets: A study of state bank of India. RET Academy for International Journals of Multidisciplinary Research, 3(3), 24-29.

3. Sahni, D. and Seth, D.C. (2017), "Non-performing assets (NPAs) in Indian commercial banks", International Journal of Engineering Science and Computing, Vol. 7 No. 4, pp. 6243-6247.

4. H. S., S. (2013), 'A study on causes and remedies for non-performing assets in Indian public sector banks with special reference to agricultural development branch, state bank of Mysore', International Journal of Business and Management Invention, Volume 2 Issue 1, PP.26-38.

5. Chaturvedi, Meenakshi. "Borrower Rating Related to Credit Risk in Commercial Banks." International Journal of Accounting and Financial Management Research (IJAFMR) 4.2 (2014): 19-26.

6. Kumar, P.T. (2013), 'A Comparative study of NPA of Old Private Sector Banks and Foreign Banks', Research Journal of Management Sciences, ISSN 2319-1171 Vol. 2(7), 38-40.

7. Mittal, R.K. and Suneja, D. (2017), "The problem of rising non-performing assets in banking sector in India: comparative analysis of public and private sector banks", International Journal of Management, IT and Engineering, Vol. 7 No. 7, pp. 384398.

8. Selvarajan, B. \&Vadivalagan, G. (2013), 'A Study on Management of Non-Performing Assets in Priority Sector reference to Indian Bank and Public Sector Banks (PSBs)', Global Journal Of Management and Business Research, Vol. 13, Issue 1.

9. Praveenkumar, S. "The Service Quality Gap Analysis-A Study on Selected Commercial Banks in Madurai." International Journal of Business Management \& Research (IJBMR), 6 (1), 65-74. Ergonomics Principles for Customer Satisfaction (2016). 
10. Singh, J. (2013), 'Recovery of NPAs in Indian commercial banks', International Journal Of Transformation in Business, Vol. 2, Issue 3.

11. Gupta, B. (2012), 'A Comparative Study of Non-Performing Assets of SBI \& Associates \& Other Public Sector Banks', SIT Journal of Management, Vol. 2, No. 3, PP. 175-189.

12. Sattar, MD Abdus. "Corporate Social Responsibility in Disaster Risk Management: A Study on Some Selected Private Commercial Banks of Bangladesh." International Journal of Environment, Ecology, Family and Urban Studies 7.5 (2017): 7 18.

13. Rai, K. (2012), 'Study on performance of NPAs of Indian commercial banks', Asian Journal of Research in Banking and finance, Vol. 2, Issue 12.

14. Khanna, P. (2012), 'Managing nonperforming assets in commercial banks', GianJyoti E-Journal, Volume 1, Issue 3 (Apr - Jun 2012) ISSN 2250-348X.

15. Bhattarai, Bisshnu Prasad. "The Determinants of Profitability of Commercial Banks in Nepal."International Journal of Accounting and Financial Management Research (IJAFMR) 9.2, Dec 2019, 15-20

16. Chatterjee, C. and Mukherjee, J. and Das, R. (2012), 'Management of non-performing assets - a current scenario', International Journal of Social Science \& Interdisciplinary Research, Vol.1 Issue 11. 